\title{
First Population Genetic Structure Analysis of the Freshwater Crab Potamon fluviatile (Brachyura: Potamidae) Reveals Fragmentation at Small Geographical Scale
}

\author{
Adriana Vella ${ }^{1, *} \mathbb{D}^{\infty}$, and Noel Vella ${ }^{1}$ \\ ${ }^{1}$ Conservation Biology Research Group, Department of Biology, University of Malta, Msida MSD2080, Malta.
}

\author{
Article History \\ Received Apr 17, 2020 \\ Accepted Jun 15, 2020 \\ First Online Jun 18, 2020
}

\section{Corresponding Author \\ Tel.: +35623402790 \\ E-mail: adriana.vella@um.edu.mt}

\section{Keywords}

Maltese archipelago

Population structure

Freshwater courses

mtDNA

Genetic connectivity

\begin{abstract}
The freshwater crab, Potamon fluviatile inhabits a number of watercourses in Italy, the Balkan Peninsula and some neighbouring islands. In this study, $P$. fluviatile specimens $(n=176)$ were tissue sampled from different watercourses in Maltese archipelago and were genetically analysed to investigate the population structure of the species within this small geographical area. The DNA sequences analysed included 622 nucleotides from cytochrome oxidase $\mathrm{c}$ subunit 1 gene, and 3160 nucleotides from the sequence between the NADH dehydrogenase subunit 6 gene and the 16S rRNA gene. Results indicated the occurrence of two main clades, with most populations exhibiting different haplotype frequencies and were characterized by private haplotypes that radiate from the main haplotype of each clade. This led to significant pairwise differences between most of the sampled populations. On grouping populations based on their geographical region, it was found that there are significantly large genetic differences between regions, with AMOVA analyses showing that over $90 \%$ of the genetic variation is due to differences between distant water systems. The population structure and the lack of genetic connectivity found among populations inhabiting different valleys highlight the urgent need for targeted conservation management of this legally protected species that is fragmented in small isolated populations.
\end{abstract}

\section{Introduction}

Potamon fluviatile (Herbst, 1785), is a crab that is found exclusively in freshwater ecosystems. Its geographical range encompasses a number of hydrographically isolated water systems in Italy; the Balkans namely Albania, Croatia, Greece, Montenegro, North Macedonia and in the Turkish Thrace region; and neighbouring islands, including the Maltese archipelago (Cumberlidge, 2008; Jesse et al., 2009; Harlıoğlu, Farhadi \& Harlıoğlu, 2018). In the Maltese archipelago, this is the only species of freshwater crabs where it represents the largest native freshwater decapod known through historic records to occur in a number of water systems
(Gavino, 1873; Pace, 1974; Jaccarini \& Harris, 1975; Pace, Harris \& Jaccarini, 1976; Capolongo \& Cilia, 1990; Cachia, 1997; Camilleri \& Cachia, 2000; Debrincat \& Schembri, 2007; Sciberras, Sciberras \& Vella, 2009).

In general, even though $P$. fluviatile is fairly widespread in various water bodies, its distribution is highly fragmented and like several other freshwater crab species, its populations have been reported to be on the decline (Cumberlidge et al., 2009), leading its IUCN Red list status to be Nearly Threatened (Cumberlidge, 2008). Much of this negative trend is attributed to a number of anthropogenic factors that are effecting freshwater bodies across Europe including pollution, habitat modification, agriculture, use of 
pesticide, water usage for irrigation and overharvesting (Barbaresi, Cannicci, Vannini \& Fratini, 2007; Cumberlidge et al., 2009; Freyhof \& Brooks, 2011; Gozlan, Karimov, Zadereev, Kuznetsova \& Brucet, 2019; Grzybowski \& Glińska-Lewczuk, 2019). Moreover, the introductions of invasive freshwater species, such as the red swamp crayfish, Procambarus clarkii, maybe adding pressure to the survival of native species due to competition for resources (Barbaresi et al., 2007; Vella, Vella \& Mifsud, 2017). In the Maltese islands, freshwater systems that persist through the year can be considered as rare and vulnerable habitats, as most of them are very restricted in range and their presence and persistence are highly influenced by the wet season, making them susceptible to climate change and increasing human activities. These factors inducing degradation of valley habitats and the loss of native species. This scenario also includes the freshwater crab's habitat where records indicate that the species had disappeared from some valleys, especially those most exposed to anthropogenic activities (Capolongo \& Cilia, 1990). In Malta, P. fluviatile females were found to lay around 200 eggs, and carry them from May to August (Pace, 1976). The timing of this season, the length of the incubation period which lasts around 46 days, the need to keep the eggs ventilated by the brooding crab while submerged (Pace, 1976) and given that after hatching the brood remains attached to the female limiting her locomotor activity (Gherardi, Messana, Ugolini \& Vannini, 1988) put more weight on the importance of safeguarding perennial freshwater systems. Their protection, especially during the dry season, should ensure that enough resources are present for the females to complete the reproductive cycle.

Previous genetic works on $P$. fluviatile looked into its classification and on past events that might have affected its current distribution as Pleistocene climatic fluctuations have influenced connectivity and refugia for the species (Jesse et al., 2009; Jesse, Schubart \& Klaus, 2010; Jesse, Grudinski, Klaus, Streit \& Pfenninger, 2011; Vecchioni et al., 2017). Some studies have led to the identification of a new species, $P$. pelops, in Greece (Jesse et al., 2011), while questioning the occurrence of the endemic subspecies, Potamon fluviatile lanfrancoi from the Maltese islands, as described in Capolongo and Cilia, 1990. Mitochondrial DNA phylogenetic studies of specimens from the Maltese islands failed to identify unique haplotypes that diverge from the continental populations of $P$. fluviatile as evidence to back the occurrence of subspecies (Jesse et al., 2009; Vecchioni et al., 2017). Moreover, morphological studies (Brandis, Storch \& Türkay, 2000) indicated that there is little morphological evidence to confirm the subspecies status of the Maltese populations of freshwater crab given that the original morphological description was based on a comparative study of small sample sizes and may have not been representative of the species.

The current study is the first of its kind to use genetic data as a tool to evaluate inter- and intra- population diversity of this species and determine how on a small geographical scale, hydrographically distinct systems may shape the spatial population structure of $P$. fluviatile. This knowledge is essential for the legally protected $P$. fluviatile, also considered as a flagship species for the conservation of the freshwater ecosystem. Conservation management would allow for better coherence between the protection of the different and distinct freshwater systems and the biodiversity they sustain, including this freshwater crab species.

\section{Materials and Methods}

\section{Study Area}

This study focuses on the populations of $P$. fluviatile in the Maltese archipelago. This archipelago is situated $80 \mathrm{~km}$ south of Sicily. During glacial periods, fluctuations in sea level have led to the formation of a land bridge connecting the Maltese Islands and the southern region of Sicily, allowing the migration and dispersal of fauna (Furlani et al., 2013).

The Maltese archipelago is characterized by two main islands, Malta and Gozo. Both islands have a few perennial streams, some of which host the species under study. The streams from which $P$. fluviatile were tissue sampled from the island of Malta (Figure 1)

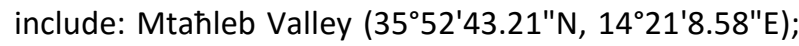

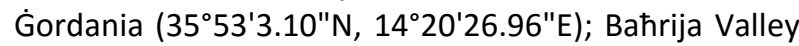
$\left(35^{\circ} 53^{\prime} 40.40^{\prime \prime} \mathrm{N}, 1^{\circ} 20^{\prime} 20.11^{\prime \prime E}\right) ;$ San Martin Valley $\left(35^{\circ} 56^{\prime} 10.79^{\prime \prime} \mathrm{N}, \quad 14^{\circ} 22^{\prime} 51.08^{\prime \prime} \mathrm{E}\right)$ and Tilliera $\left(35^{\circ} 56^{\prime} 19.61^{\prime \prime} \mathrm{N}, 14^{\circ} 22^{\prime} 43.51^{\prime \prime E}\right)$. On the island of Gozo (Figure 1), P. fluviatile specimens were tissue sampled from the watercourse of the valley system that stretches from Lunzjata to Xlendi (36²'5.56"N, $\left.14^{\circ} 13^{\prime} 56.85^{\prime \prime E}\right)$.

\section{Sample Collection and DNA Extraction}

176 specimens of $P$. fluviatile were sampled (132 tissue samples from live specimens and 44 tissue samples from dead specimens) along the stream of six different valley systems in the Maltese Islands, between 2018 and 2019 (Figure 1). Live specimens were sampled through the collection of one walking leg as indicated in Permit NP 0176/18/33A and tissues from dead specimens were collected as indicated by Permit NP $0386 / 18 / 1 B$. Upon collection, the tissue samples were stored in $100 \%$ ethanol. The genomic DNA was extracted from $5 \mathrm{mg}$ of tissue using GF-1 Tissue DNA Extraction Kit (Vivantis Technologies, Malaysia) following the manufacturer's manual. The purified DNA was stored at $-20^{\circ} \mathrm{C}$.

\section{PCR Amplification and Sequencing}

The mtDNA regions analysed in this study were: the partial cytochrome oxidase $\mathrm{C}$ subunit 1 (COI) sequence; and the sequence between the $\mathrm{NADH}$ 


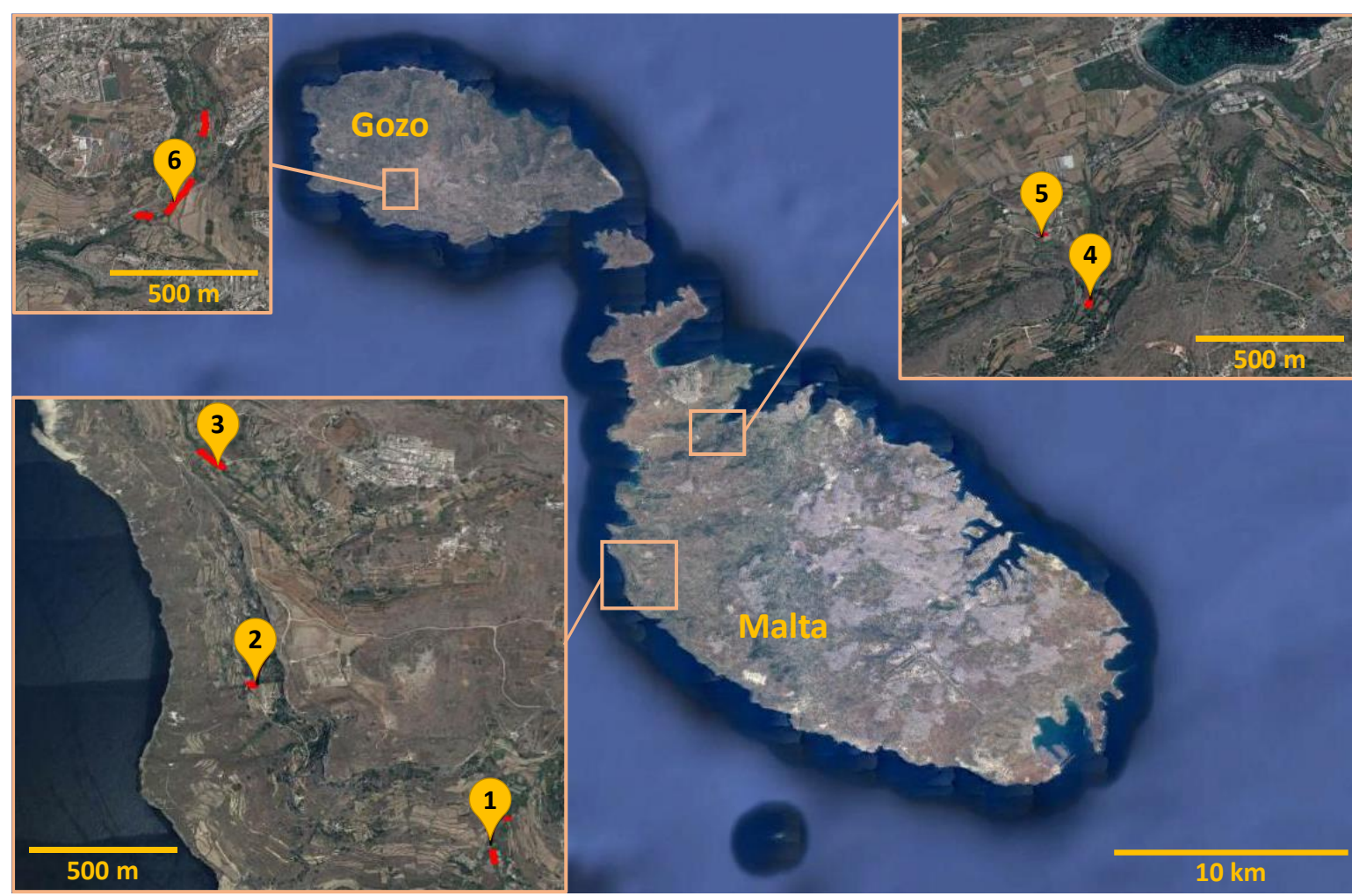

Figure 1. A map (Google Earth, 2019) of the Maltese Islands showing the six sampling locations analysed in this study. Malta: 1.

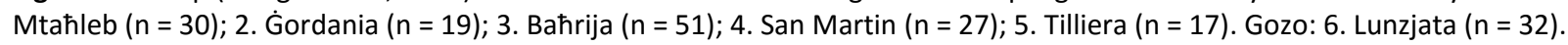

dehydrogenase subunit 6 gene (ND6) and the 16S rRNA gene (16S), that include the partial ND6 gene, the complete cytochrome B gene (cytB), tRNA-Ser gene, NADH dehydrogenase subunit 1 gene (ND1), tRNA-Leu, partial $16 \mathrm{~S}$ gene and few non-coding bases. These two regions were amplified through the use of seven new primer sets (Table 1 ) that were specifically designed for this study. The mtDNA sequences were amplified in 25 $\mu \mathrm{L}$ reaction volumes using $100 \mathrm{ng}$ DNA template; $1 \times$ HOT FIREPol ${ }^{\circledR}$ Master Mix [1.5 $\mathrm{mM} \mathrm{Mg}^{2+}, 200 \mu \mathrm{M}$ each dNTP, HOT FIREPol ${ }^{\circledR}$ DNA polymerase] (Solis BioDyne, Estonia); and $0.2 \mu \mathrm{M}$ of each primer.

The cycle conditions for PCR reactions 1,3 and 4 were $95^{\circ} \mathrm{C}$ for $15 \mathrm{~min}$, followed by 35 cycles of $95^{\circ} \mathrm{C}$ for $45 \mathrm{~s}, 59^{\circ} \mathrm{C}$ for $1 \mathrm{~min}, 72{ }^{\circ} \mathrm{C}$ for $1 \mathrm{~min}$, and $72{ }^{\circ} \mathrm{C}$ for 10 min, while the cycle conditions for PCR reactions $2,5,6$ and 7 followed the same temperature profile but with a $\mathrm{T}_{\mathrm{a}}$ of $50{ }^{\circ} \mathrm{C} .1 \mu \mathrm{L}$ aliquots of the PCR reaction mixtures were electrophoresed on $1.5 \%$ agarose gels stained with ethidium bromide, to confirm amplification and PCR product sizes. PCR products were sequenced using the respective forward and reverse primers via 3730XL Genetic Analyzer (Life Technologies, USA).

\section{Statistical Analyses}

Once the data set for each individual specimen sampled was obtained, the sequences were trimmed to remove ambiguous bases at the ends, assembled and manually checked for consistencies. The protein-coding genes were checked for indels and stop codons using Geneious R10 (Kearse et al., 2012), while the folding and identification of tRNA genes was done with Geneious R10 (Kearse et al., 2012) and tRNAscan-SE 2.0 (Chan \& Lowe, 2019). Unique haplotypes were reanalysed through a second PCR to confirm the genetic differences

Table 1. Primer sets designed for the current study

\begin{tabular}{|c|c|c|c|c|}
\hline Reaction & & Forward primer sequence & & Reverse primer sequence \\
\hline 1 & COlaF & 5'CCATCGCTTATATCTCAGCCACT & COlaR & 5'ACAATATGAGAAACTATACCAAATGCT \\
\hline 2 & $N D 6 a F$ & 5'CTCGTTTATCTCACCCCCTAGC & ND6aR & 5'ACGCATGGAAAATTATATAAGATCCGT \\
\hline 3 & CYTb1F & 5'TCACACATTGATTTAGCATTCTCA & CYTb1R & 5'TCTTCGAAATTTTTGATAAATGGGT \\
\hline 4 & $C Y T b 2 F$ & 5'TCCССTTTCTACTССТGCTCA & $C Y T b 2 R$ & 5’TATAGAGGCGGCGGATTTGC \\
\hline 5 & ND1aF & 5'TGGGCAGATATCTTTTTTCACGC & ND1aR & 5'GGTAGTTGTACCGTATAAAGTAGGA \\
\hline 6 & $N D 1 b F$ & 5'AAAGCCAATCTAACTTCATAAGAAA & $N D 1 b R$ & 5'TGCAGAGGCTATAAGAGAAGGTC \\
\hline 7 & LeuF & 5'TGCATATTCTCTGCCAAAACAGT & $16 R$ & 5'TGCCTGTTTATCAAAAACATGTCT \\
\hline
\end{tabular}


noted. Sequences were then deposited in GenBank under accession numbers MT522008-10 and MT521491-8. The mtDNA COI and ND6 data of each individual were concatenated, and the final data set was aligned via MUSCLE alignment using 1,000 iterations embedded in Geneious R10 (Kearse et al., 2012). Genetic variability was detected through Geneious R10 (Kearse et al., 2012) and MEGA v7 (Kumar, Stecher \& Tamura 2015). DnaSP v6.11 (Rozas et al., 2017) was used to identify the number of haplotypes per location. Rarefaction analyses were conducted via Analytic Rarefaction v1.3 (UGA Stratigraphy Lab, 2013) to check whether sample sizes from the various sampling locations analysed in this study were able to capture representative genetic diversity.

The concatenated data was also used to calculate the genetic diversity indices at each location using Arlequin v3.5 (Excoffier \& Lischer, 2010). These indices included estimates of haplotype diversity $(h)$, nucleotide diversity $(\pi)$ and pairwise differences. A minimum spanning haplotype network showing the genetic association between various haplotypes at the various sampling locations was constructed using TCS v1.21 (Clement, Posada \& Crandall, 2000), while a NeighbourJoining tree was constructed using Kimura-2-parameter (Kimura, 1980) and 1000 bootstrap replicates via MEGA v7 (Kumar, Stecher \& Tamura 2015). The chi-squared test was used to determine whether the haplotypes were randomly distributed or whether they were clustered according to locations.

The concatenated data was also used for estimating the pairwise $\phi$ st values between sampling locations. These values were calculated using 100,000 permutations, via Arlequin v3.5 (Excoffier \& Lischer, 2010), utilizing Kimura-2-parameter (Kimura, 1980) for the $\phi_{\text {sт }}$ estimates, as it was identified as the model of best fit for DNA evolution as selected with AICC and BIC in jModelTest 2.1.7 (Darriba, Taboada, Doallo \& Posada, 2012). The individual locations were then grouped into regions based on their geographical proximity:

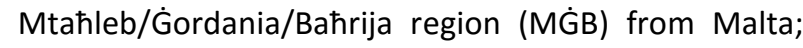
San Martin/Tilliera region (ST) from Malta; and Lunzjata area from Gozo. This regional grouping was then analysed for estimates of pairwise $\phi_{\text {ST }}$ values, followed by analysis of molecular variance (AMOVA) that was also conducted via Arlequin v3.5 (Excoffier \& Lischer, 2010) using the model of best fit as identified earlier by jModelTest (Darriba et al., 2012).

The populations and regions that exhibited variance were analysed for expansion estimates using mismatch distributions (Schneider \& Excoffier, 1999) between the haplotypes identified. Arlequin v3 (Excoffier \& Lischer, 2010) was used to detect evidence of expansion by assessing the fit of the simulated mismatch distributions with the sum of square deviations (SSD) and Harpending's Raggedness Index (Harpending, Sherry, Rogers \& Stoneking, 1993; Excoffier \& Lischer, 2010) using 10,000 permutations. Apart from displaying a star-shaped haplotype network, with these tests, populations in expansion should display a unimodal distribution as opposed to populations that are in equilibrium and thus display a multimodal distribution of pairwise differences (Slatkin \& Hudson, 1991; Rogers \& Harpending, 1992; Harpending \& Rogers, 2000). Nonetheless, recent demographic fluctuations in population sizes may not be noticeable using mismatch distribution analyses as previous events may mask the effects of recent events (Rogers \& Harpending, 1992; Harpending \& Rogers, 2000). Arlequin v3 (Excoffier \& Lischer, 2010) was also used to perform Tajima's D (Tajima, 1989) and Fu's Fs neutrality tests (Fu, 1994; 1997) using 10,000 replicates.

\section{Results}

The mtDNA regions analysed in this study added up to 3782 nucleotides of which 622 nucleotides were from the COI gene and 3160 nucleotides of the ND6 gene to $16 \mathrm{~S}$ rRNA gene sequence. The latter region included 306 nucleotides from ND6 gene, 1135 nucleotides from cytB gene, 67 nucleotides from tRNA-Ser gene, 17 nucleotides non-coding, 942 nucleotides from ND1 gene, 30-31 nucleotides non-coding, 65 nucleotides tRNA-Leu gene and the 599 nucleotides from the $3^{\prime}$ of the $16 \mathrm{~S}$ gene, with the latter three genes being coded on the L-strand. The sequences obtained for the 176 specimens analysed were readable, did not exhibit ambiguous bases, were free from indels and stop codons on the protein-coding genes and had the expected tRNA folding patterns for these respective genes on ARWEN and tRNAscan-SE 2.0 (Laslet \& Canbäck, 2008; Chan \& Lowe, 2019), thus making the inclusion of pseudogenes for the newly studied mtDNA sequences very unlikely. The length of the mtDNA sequence analysed in this study expands on the variation that would have been noted through previous study protocols set for the Potamon species (Jesse et al., 2009, 2010, 2011; Keikhosravi, Fratini, Christoph \& Schubart, 2015; Vecchioni et al., 2017). This led to the identification of more genetic differences and to better segregation of haplotypes between locations with a higher level of confidence.

All genes exhibited some genetic variation, except ND6 and the tRNAs. The most variable sites were noted in COI, cytB and ND1 which had $0.6 \%, 1.1 \%$ and $1.3 \%$ respectively. Concatenated data produced a total of 30 variable positions, of which 27 were transitions, 2 were transversions and 1 was an indel, with 27 of these being parsimony-informative sites. This variation led to the formation of 9 haplotypes (Table 2) with an overall haplotype diversity index of 0.583 (SD: \pm 0.021 ) and an overall nucleotide diversity index of 0.0030 (SD: \pm 0.0015$)$. The haplotypes recorded in this study revealed two clades that were separated from each other by 22 mutational steps (Figure 2 and 3), with clade $A$ being represented by 5 haplotypes (53.4\% of the analysed specimens), while clade $B$ being represented by 4 haplotypes ( $46.6 \%$ of the analysed specimens) 
Table 2. The genetic differences between the 9 haplotypes ( $\mathrm{H} 1$ to $\mathrm{H} 9$ ) identified in this study. The numbers on top indicate the position of the genetic difference in the two analysed sections of the mtDNA. The haplotypes 1 to 5 are from clade $A$ and haplotypes 6 to 9 are from clade $B$.

\begin{tabular}{|c|c|c|c|c|c|c|c|c|c|c|c|c|c|c|c|c|c|c|c|c|c|c|c|c|c|c|c|c|c|c|c|}
\hline & & \multicolumn{4}{|c|}{ COI gene } & \multicolumn{9}{|c|}{ ND6 gene to $16 S$ gene } & \multirow{2}{*}{$\begin{array}{l}1 \\
0\end{array}$} & \multirow{2}{*}{$\begin{array}{l}1 \\
0\end{array}$} & \multirow{2}{*}{$\begin{array}{l}1 \\
4\end{array}$} & \multirow{2}{*}{$\begin{array}{l}1 \\
8\end{array}$} & \multirow{2}{*}{$\begin{array}{l}1 \\
8\end{array}$} & \multirow{2}{*}{$\begin{array}{l}2 \\
1\end{array}$} & \multirow{2}{*}{$\begin{array}{l}2 \\
1\end{array}$} & \multirow{2}{*}{$\begin{array}{l}2 \\
1\end{array}$} & \multirow{2}{*}{$\begin{array}{l}2 \\
2\end{array}$} & \multirow{2}{*}{$\begin{array}{l}2 \\
3\end{array}$} & \multirow{2}{*}{$\begin{array}{l}2 \\
3\end{array}$} & \multirow{2}{*}{$\begin{array}{l}2 \\
3\end{array}$} & \multirow{2}{*}{$\begin{array}{l}2 \\
3\end{array}$} & \multirow{2}{*}{$\begin{array}{l}2 \\
4\end{array}$} & \multirow{2}{*}{$\begin{array}{l}2 \\
4\end{array}$} & \multirow{2}{*}{$\begin{array}{l}2 \\
4\end{array}$} & \multirow{2}{*}{$\begin{array}{l}2 \\
7\end{array}$} \\
\hline & & & & 3 & 3 & 3 & 3 & 4 & 5 & 5 & 5 & 6 & 7 & 8 & & & & & & & & & & & & & & & & & \\
\hline & & 8 & 9 & 0 & 5 & 7 & 8 & 0 & 0 & 5 & 9 & 4 & 0 & 2 & 4 & 9 & 0 & 0 & 7 & 1 & 6 & 8 & 6 & 2 & 3 & 6 & 9 & 1 & 4 & 8 & 6 \\
\hline & & 4 & 0 & 9 & 4 & 1 & 1 & 1 & 7 & 1 & 5 & 4 & 4 & 4 & 2 & 1 & 7 & 0 & 4 & 7 & 0 & 0 & 4 & 5 & 7 & 1 & 1 & 5 & 8 & 3 & 6 \\
\hline \multirow{5}{*}{$\begin{array}{l}\frac{\pi}{0} \\
\frac{0}{0} \\
\frac{\pi}{U}\end{array}$} & $\mathrm{H} 1$ & C & $A$ & $\mathrm{~T}$ & G & $A$ & $\mathrm{G}$ & $\mathrm{G}$ & $A$ & G & C & $\mathrm{G}$ & $\mathrm{T}$ & C & $\mathrm{T}$ & C & G & G & $\mathrm{T}$ & C & G & $\mathrm{T}$ & C & $\mathrm{T}$ & C & G & C & $\mathrm{T}$ & C & 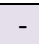 & $\mathrm{G}$ \\
\hline & $\mathrm{H} 2$ & . & . & . & . & . & . & . & . & . & . & . & . & . & . & . & . & . & . & . & . & C & . & . & . & . & . & . & . & - & . \\
\hline & $\mathrm{H} 3$ & . & . & . & . & . & . & . & . & . & . & . & . & . & G & . & . & . & . & . & . & . & . & . & . & . & . & . & . & - & . \\
\hline & $\mathrm{H} 4$ & . & . & . & . & G & . & . & . & . & . & . & . & . & . & . & . & . & . & . & . & . & . & . & . & . & . & . & . & - & . \\
\hline & H5 & . & . & . & . & . & . & . & . & . & & . & . & . & . & . & . & . & . & . & . & . & . & C & . & . & . & . & . & - & . \\
\hline \multirow{4}{*}{$\begin{array}{l}\infty \\
\frac{0}{0} \\
\frac{\pi}{U}\end{array}$} & $\mathrm{H} 6$ & . & G & C & $A$ & . & $A$ & . & G & $A$ & & $A$ & C & $\mathrm{T}$ & . & G & $A$ & $A$ & C & . & $A$ & . & $\mathrm{T}$ & . & $\mathrm{T}$ & $A$ & $\mathrm{~T}$ & C & $\mathrm{T}$ & $A$ & A \\
\hline & $\mathrm{H} 7$ & . & $\mathrm{G}$ & C & $A$ & 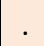 & $A$ & . & $\mathrm{G}$ & $A$ & $\mathrm{~T}$ & $A$ & C & $\mathrm{T}$ & . & G & $A$ & $A$ & C & . & A & . & $\mathrm{T}$ & . & $\mathrm{T}$ & $A$ & $\mathrm{~T}$ & C & $\mathrm{T}$ & $A$ & A \\
\hline & $\mathrm{H} 8$ & . & $\mathrm{G}$ & $\mathrm{C}$ & $A$ & . & $A$ & $A$ & $\mathrm{G}$ & $A$ & & $A$ & C & $\mathrm{T}$ & . & $\mathrm{G}$ & $A$ & $A$ & C & $\mathrm{T}$ & $A$ & . & $\mathrm{T}$ & . & $\mathrm{T}$ & $A$ & $\mathrm{~T}$ & $\mathrm{C}$ & $\mathrm{T}$ & $A$ & A \\
\hline & $\mathrm{H} 9$ & $\mathrm{~T}$ & $\mathrm{G}$ & C & A & . & A & . & G & $A$ & . & A & C & $\mathrm{T}$ & . & $\mathrm{G}$ & A & A & C & . & A & . & $\mathrm{T}$ & . & $\mathrm{T}$ & A & $\mathrm{T}$ & C & $\mathrm{T}$ & A & A \\
\hline
\end{tabular}

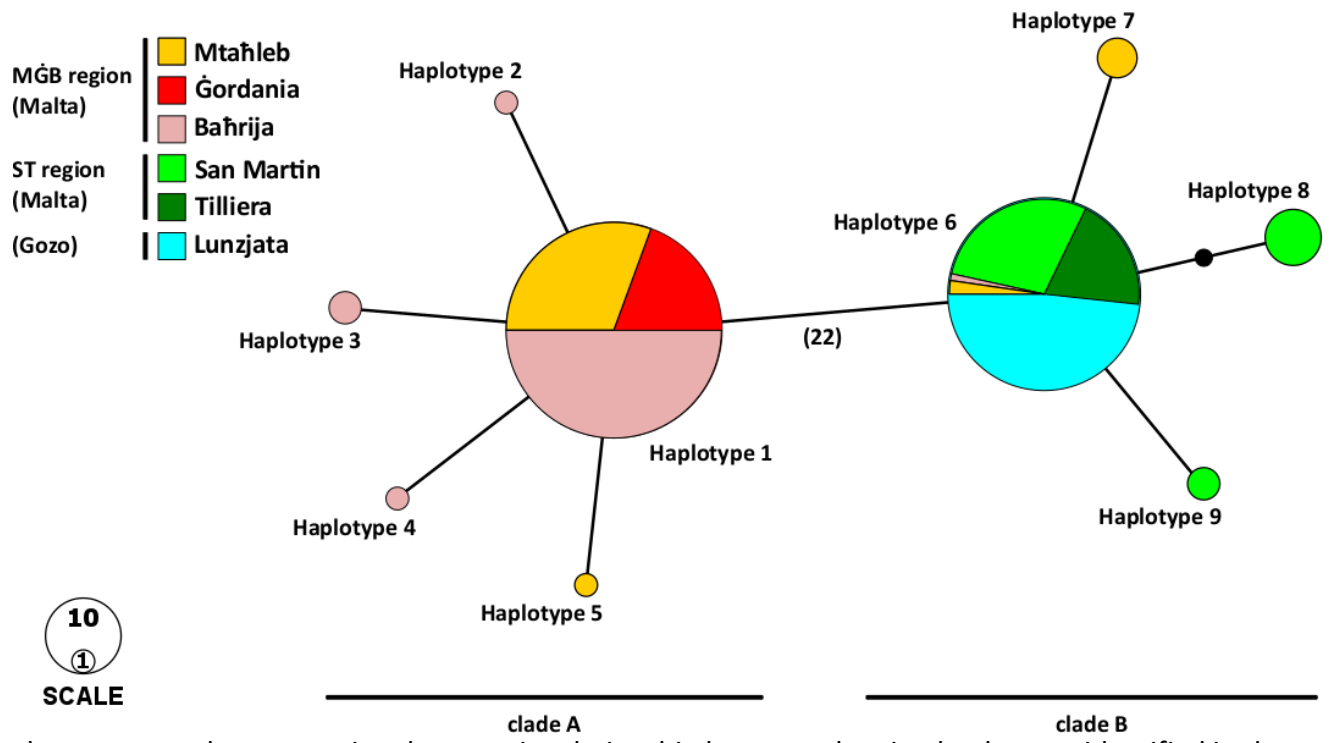

Figure 2. A haplotype network representing the genetic relationship between the nine haplotypes identified in the current study [haplotype frequencies are proportional to the area of the circles, colours are related to sampling locations, the black unlabelled circle represents an inferred putative haplotype that was not observed during this study and the number in the brackets indicate the number of mutational steps present between the two main haplotypes identified in this study].

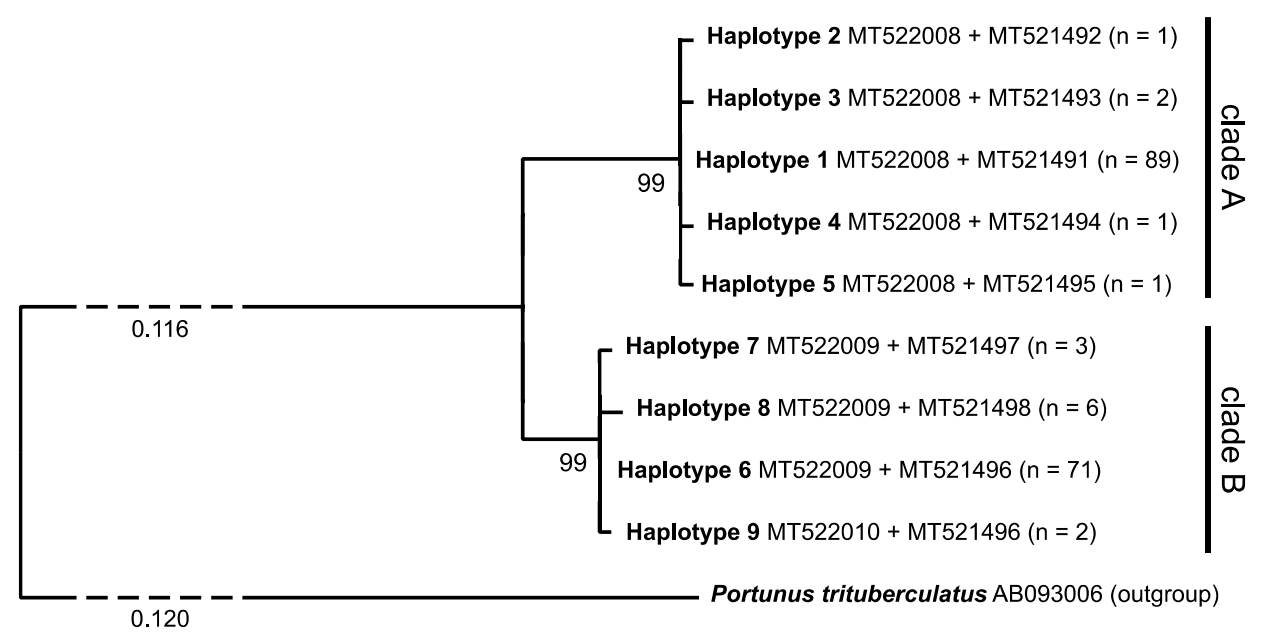

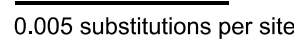

Figure 3. A Neighbour-Joining tree showing the phylogeny of the 9 haplotypes identified in this study. Bootstrap values are shown at their respective nodes. The accession numbers on the right represent the concatenated sequence for each respective haplotype (COI + ND6 to 16S). Portunus trituberculatus (AB093006 - Yamauchi, Miya \& Nishida, 2003) was used as outgroup. 
(Table 2; Figure 2 and 3). Each clade was defined by the main haplotype, $\mathrm{H} 1(n=89)$ representing $94.7 \%$ of the haplotypes of clade $A$ and $H 6(n=71)$ representing $86.6 \%$ of the haplotypes of clade B. A few rare haplotypes radiated from the main haplotype found at each clade. Although there is always the possibility that larger sample sizes from the various populations might have led to the detection of other haplotypes, rarefaction analyses of the current data sets of each sampled location produced curves that closely reached a plateau with converging $95 \%$ confidence intervals, indicating that the sampling strategy of this study allowed for the representation of most haplotypes present in the respective areas.

\section{Genetic Diversity and Population Structure}

This study shows that haplotypes are not randomly distributed (Chi-squared, P-value $<0.0001$ ), therefore indicating that the haplotypes are clustered according to the water system under study (Table 3 ). In fact, the overall haplotype diversity was higher $(0.583)$ than the haplotype diversity noted in each sampling location (zero - 0.467), indicating that in most cases there was little haplotype diversity within populations as opposed to the overall diversity. The same applies to the nucleotide diversity, where the overall nucleotide diversity was 0.0030 as opposed to the lower nucleotide diversity noted within populations (zero - 0.0017), indicating that within populations the haplotypes noted are more closely related (Table 3).

The haplotype network was characterized by the segregation of haplotypes between geographic regions, indicating an association between haplotypes and sampling locations. Haplotypes from clade A accounted for $94.0 \%$ of the sampled specimens from the MGंB region (Malta); while specimens from the ST region (Malta) and Lunzjata area (Gozo) exhibited only haplotypes from clade B (Figure 2). H1 was the most common haplotype found at Mtaћleb, Gordania and Bahrija (Malta) with an occurrence of $80.0 \%, 100 \%$ and $90.2 \%$ at each respective location. $\mathrm{H} 6$ was found to be a

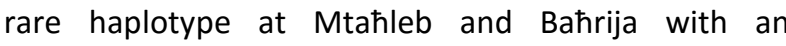
occurrence of $6.7 \%$ and $2.0 \%$ respectively, while at San Martin, Tilliera (Malta) and Lunzjata (Gozo) this haplotype was the most common haplotype occurring in $70.4 \%, 100 \%$ and $100 \%$ of the individuals at each respective location. The other rarer haplotypes were private to the locations they were identified at and radiated from the two most common haplotypes (Figure 2). These private haplotypes included $\mathrm{H} 5$ and $\mathrm{H} 7$ that were only found at Mtahleb; $\mathrm{H} 2, \mathrm{H} 3$ and $\mathrm{H} 4$ were only found at Bahrija; and $\mathrm{H} 8$ and $\mathrm{H} 9$ were only noted at San Martin.

Pairwise $\phi$ st values have shown that in most cases there was large significant pairwise genetic differentiation between populations (Table 4). Mtaћleb vs Bahrija showed low but significant genetic distance differentiation $(\phi \mathrm{st}=0.118, P$-value $=0.007$ ) as both shared the same common haplotype, while at the same time each was characterized by 2 and 3 private haplotypes respectively. However, the small population of Gordania, which is geographically located between

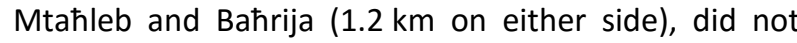
significantly differ from the latter two populations ( $\phi \mathrm{ST}=$ $0.099, P$-value $=0.140 ; \phi$ ST $=<0.000, P$-value $=0.844)$. Almost all specimens of these three geographically close locations were represented by haplotypes from clade A, and thus significantly differed from the other studied populations that were defined exclusively by haplotypes from clade $B$.

Even though on different islands, the population sampled from Lunzjata (Gozo) showed no genetic differentiation from that at Tilliera (Malta). This is attributed to the lack of haplotype diversity noted at these locations, as both exhibited the same haplotype indicating that there could be a recent founder effect or incomplete lineage sorting at these locations. In fact, it is highly probable that the population at Tilliera may have been founded by individuals possessing the most common haplotype present in the San Martin population (San Martin vs Tilliera $\phi_{\mathrm{ST}}=0.129, P$-value $=$ $0.046)$. This is possible as the Tilliera population is very small and separated by approximately $250 \mathrm{~m}$ of cultivated land from the upstream San Martin population. Such habitat offers the right conditions for the movement of individuals between the separate watercourses, especially during the wet season. On the other hand, the population at Lunzjata in Gozo, though well established, lacks haplotype diversity contrasting with similarly large populations on the island of Malta,

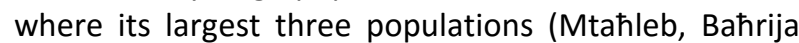
and San Martin) exhibited multiple private haplotypes. The former lack of diversity may be an indication of the decline of this population where individuals may be passing through several bottlenecks with periods of population declines limiting the population expansion and genetic diversity.

Regional analyses on the basis of their geographical distribution (Table 5; $\phi_{\text {ST }}$ values 0.084 $0.905, P$-values $<0.05)$ reconfirmed that there is clear genetic segregation between regions. AMOVA analyses of the regional data using a pairwise distance matrix of MǴB (Malta) against ST (Malta) against Lunzjata (Gozo) yielded the highest variation amongst groups with $90.8 \%$ of the genetic variation being recorded between these three regions as opposed to the $9.2 \%$ variation within each region $(P$-value $<0.001)$.

Comparison with previous $P$. fluviatile works was limited as research prior to this study was based on shorter sequences of $\mathrm{COI}$ and ND1 genes. Nonetheless, on comparing parts of our sequence data with current international data on GenBank (NCBI, 2020), it was noted that four haplotypes from three of the sampling locations of the current study were found to be endemic (H2, H5, H8 and H9). Such comparison used only homologous data which is less than half of the sequence length analysed in this study. Had there been longer 
Table 3. The number of specimens ( $\mathrm{n}$ ) per haplotype, the haplotype diversity index $(h)$ and the nucleotide diversity index $(\pi)$ at each sampled location

\begin{tabular}{|c|c|c|c|c|c|c|c|c|c|c|c|c|}
\hline Location & $\mathrm{n}$ & H1 & $\mathrm{H} 2$ & H3 & $\mathrm{H} 4$ & H5 & H6 & $\mathrm{H} 7$ & H8 & $\mathrm{H9}$ & $h$ & $\pi$ \\
\hline Mtaћleb & 30 & 24 & & & & 1 & 2 & 3 & & & $0.356 \pm 0.106$ & $0.0017 \pm 0.0009$ \\
\hline Ġordania & 19 & 19 & & & & & & & & & - & - \\
\hline Baћrija & 51 & 46 & 1 & 2 & 1 & & 1 & & & & $0.188 \pm 0.073$ & $0.0003 \pm 0.0002$ \\
\hline San Martin & 27 & & & & & & 19 & & 6 & 2 & $0.467 \pm 0.094$ & $0.0002 \pm 0.0002$ \\
\hline Tilliera & 17 & & & & & & 17 & & & & - & - \\
\hline Lunzjata & 32 & & & & & & 32 & & & & - & - \\
\hline Overall & 176 & 89 & 1 & 2 & 1 & 1 & 71 & 3 & 6 & 2 & $0.583 \pm 0.021$ & $0.0030 \pm 0.0015$ \\
\hline
\end{tabular}

Table 4. The pairwise $\phi_{\mathrm{ST}}$ values (below diagonal) and P-values (above diagonal) for the (a) sampled locations and (b) for the sampled regions. Highlighted values indicate significant difference at $\mathrm{P}$-value $<0.05$

\begin{tabular}{|c|c|c|c|c|c|c|}
\hline (a) Location & Mtaћleb & Ġordania & Baћrija & San Martin & Tilliera & Lunzjata \\
\hline Mtaћleb & & 0.140 & 0.007 & $<0.001$ & $<0.001$ & $<0.001$ \\
\hline Ġordania & 0.099 & & 0.844 & $<0.001$ & $<0.001$ & $<0.001$ \\
\hline Baћrija & 0.118 & 0.000 & & $<0.001$ & $<0.001$ & $<0.001$ \\
\hline San Martin & 0.798 & 0.977 & 0.957 & + & 0.046 & 0.001 \\
\hline Tilliera & 0.781 & 1.000 & 0.965 & 0.129 & 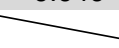 & 0.999 \\
\hline Lunzjata & 0.827 & 1.000 & 0.971 & 0.188 & \multirow{2}{*}{\multicolumn{2}{|c|}{$\frac{0.000}{\text { Lunzjata (Gozo) }}$}} \\
\hline \multicolumn{2}{|l|}{ (b) Region } & MǴB (Malta) & \multicolumn{2}{|c|}{ ST (Malta) } & & \\
\hline \multirow{3}{*}{$\begin{array}{l}\text { MGB (Malta) } \\
\text { ST (Malta) } \\
\text { Lunzjata (Gozo) }\end{array}$} & & & \multicolumn{2}{|c|}{$<0.001$} & \multicolumn{2}{|c|}{$<0.001$} \\
\hline & & \multirow{2}{*}{$\begin{array}{l}0.905 \\
0.905\end{array}$} & \multirow{2}{*}{\multicolumn{2}{|c|}{0.084}} & \multirow{2}{*}{\multicolumn{2}{|c|}{0.0263}} \\
\hline & & & & & & \\
\hline
\end{tabular}

Table 5. Sample sizes, number of nucleotide substitutions per population, the results of the neutrality tests Tajima's D and Fu's Fs and mismatch distribution values using the demographic and spatial expansion models for $P$. fluviatile populations that displayed a degree of variance in the Maltese archipelago

\begin{tabular}{|c|c|c|c|c|c|c|c|c|c|}
\hline & & Mtaћleb & Baћrija & $\begin{array}{l}\text { San } \\
\text { Martin }\end{array}$ & $\begin{array}{l}\text { MǴB } \\
\text { region }\end{array}$ & $\begin{array}{l}\text { ST } \\
\text { Region }\end{array}$ & Overall & clade A & clade B \\
\hline & Sample size & 30 & 51 & 27 & 100 & 44 & 176 & 94 & 82 \\
\hline & Substitutions & 23 & 24 & 3 & 26 & 3 & 30 & 4 & 4 \\
\hline \multirow{4}{*}{ 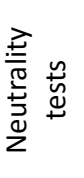 } & Tajima's D & 0.293 & -2.651 & 0.256 & -1.473 & -0.366 & 3.311 & -1.733 & -1.047 \\
\hline & P-value & 0.673 & $<0.001$ & 0.653 & 0.044 & 0.391 & 0.999 & 0.005 & 0.165 \\
\hline & Fu's Fs & 9.452 & -0.047 & 1.148 & 2.562 & 0.581 & 20.485 & -6.429 & -1.072 \\
\hline & $P$-value & 0.995 & 0.507 & 0.728 & 0.856 & 0.589 & 0.995 & $<0.000$ & 0.240 \\
\hline \multirow{7}{*}{ 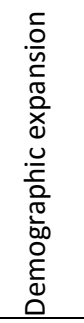 } & Tau & 3.0 & 3.0 & 3.0 & 3.0 & 3.0 & 22.2 & 3.0 & 3.0 \\
\hline & Theta 0 & 0.000 & 0.000 & 0.000 & 0.000 & 0.000 & 0.000 & 0.000 & 0.000 \\
\hline & Theta $_{1}$ & 0.382 & 0.218 & 0.382 & 0.203 & 0.465 & 1.223 & 0.120 & 0.307 \\
\hline & SSD & 0.068 & 0.002 & 0.337 & 0.011 & 0.045 & 0.231 & $<0.000$ & 0.013 \\
\hline & P-value & 0.090 & 0.340 & 0.000 & 0.217 & 0.105 & 0.066 & 0.302 & 0.265 \\
\hline & $\mathrm{HRI}$ & 0.377 & 0.469 & 0.377 & 0.505 & 0.438 & 0.433 & 0.641 & 0.434 \\
\hline & $P$-value & 0.520 & 0.640 & 0.520 & 0.665 & 0.458 & 0.130 & 0.728 & 0.583 \\
\hline \multirow{7}{*}{ 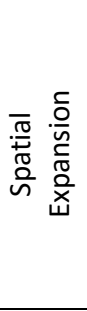 } & Tau & 23.7 & 0.1 & 1.9 & 23.5 & 1.85 & 23.0 & 0.025 & 1.421 \\
\hline & Theta & 0.134 & 0.177 & 0.001 & 0.136 & 0.001 & 0.229 & 0.119 & 0.001 \\
\hline & $\mathrm{M}$ & 0.449 & 1.394 & 0.449 & 0.133 & 0.651 & 1.262 & 0.519 & 0.501 \\
\hline & SSD & 0.031 & 0.002 & 0.031 & 0.005 & 0.019 & 0.142 & $<0.000$ & 0.003 \\
\hline & P-value & 0.416 & 0.313 & 0.416 & 0.366 & 0.369 & 0.041 & 0.301 & 0.468 \\
\hline & $\mathrm{HRI}$ & 0.377 & 0.469 & 0.378 & 0.505 & 0.438 & 0.433 & 0.641 & 0.434 \\
\hline & P-value & 0.770 & 0.617 & 0.770 & 0.744 & 0.625 & 0.324 & 0.724 & 0.676 \\
\hline
\end{tabular}


online sequences available for comparison, then the number of endemic haplotypes may have been even higher.

\section{Demographic Analyses}

Demographic parameter estimates for populations that exhibited a degree of haplotype richness indicated that the population at Baћrija has undergone expansion, as both its Tajima's D and Fu's Fs values were negative indicating an excess of rare haplotypes (Table 5). When the two clades were analysed separately, each clade generated a fairly smooth unimodal mismatch distribution graph with non-significant SSD values and Harpending's raggedness index (Table 5 ) suggesting that in the Maltese islands the population of $P$. fluviatile may have originated from $\mathrm{H} 1$ and $\mathrm{H} 6$, two ancestral haplotypes each of which led to the evolution of the other less common haplotypes in each respective clade. This outcome is also reflected through the star-shaped haplotype network within each clade (Figure 2), which was further corroborated through negative Tajima's D and Fu's Fs values (Table 5) demonstrating an excess of rare haplotypes with singleton mutations, especially for clade $A$ where these values were significantly negative. This scenario suggests a population expansion under both demographic and spatial expansion models, with such event probably happening after colonizing the Maltese archipelago given that the star-shaped network was characterized by endemic rare haplotypes. Homologous sequences of the two haplotypes with the highest occurrence, $\mathrm{H} 1$ and $\mathrm{H} 6$, also matched the most common haplotypes found in continental populations of P. fluviatile (Jesse et al., 2009) further corroborating this theory.

\section{Discussion}

This is the first population study to document the spatial intraspecific genetic variation and population structure of $P$. fluviatile within a small geographical scale. New mtDNA amplification protocols, specific to $P$. fluviatile, were designed to increase the sensitivity of the sequences analysed and to ensure that rare population-specific haplotypes were detected. At the same time, adequate sample sizes from each sampling location were used, as indicated through rarefaction curves, indicating minimized bias in the recorded haplotype ratios, given that smaller sample sizes would have caused the occurrence of rare haplotypes to be either overlooked or inflated, skewing the data and outcomes away from the actual situation present in the locations considered.

The current study shows that the mtDNA haplotypes represent two main lineages, as found by Jesse et al., (2009) where through ND1 gene data these two lineages differed from each other by 9 mutational steps. However, in our study, using a longer mtDNA sequence, the two lineages differed by 22 mutational steps. The occurrence of these two lineages suggests that the species in the Maltese islands has been founded through the most common haplotypes found on mainland Europe and then further differentiated to form rarer, endemic haplotypes distributed among the fragmented populations. These outcomes indicate that $P$. fluviatile populations from the Maltese archipelago represent genetically and thus evolutionarily separate units. This significant genetic differentiation between populations from different hydrogeographically separated habitats matched the population structure noted in similar freshwater species elsewhere (Gouin, Grandjean, Bouchon, Reynolds \& Souty-Grosset, 2001; Gouin, Souty-Grosset, Borquez, Bertin \& Grandjean, 2010; Fratini et al., 2005; Keikhosravi et al., 2015; Chen, Shih, Chu, Lee \& Tzeng, 2017; Laggis et al., 2017; Daniels, Gouws \& Crandall, 2019; Duncan, Robertson, Fletcher \& Austin, 2019; Parvizi et al., 2019). Freshwater crabs are reported to have very low dispersion ability where individuals tend to remain confined to the same freshwater system and avoid crossing long terrestrial distances between different water systems (Daniels et al., 2006). Moreover, their life-history is characterized by a prolonged brood-carrying phase (Pace et al., 1976; Micheli, Gherardi \& Vannini, 1990), thus lowering the possibility of the young to disperse with currents or water flow, especially when water flow is weak or fragmented.

In the Maltese islands, the freshwater habitats are highly fragmented and increasingly dry around each fragment, due to spreading built environment, seasonal cultivated land with dry summers, exposed cliffs and karstland, making it a life-threatening risk for crabs trying to extend their search for a mate or suitable habitat. Additionally, these conditions might restrict the plasticity in the foraging strategies, especially that of females as they tend to extend their home range and diversify their foraging behaviour to accommodate changes in dietary requirements at different stages of their life-history (Ghererdi, Tarducci \& Micheli, 1989). Perennial streams are valuable for the conservation of $P$. fluviatile, so there have to be clear management goals to maintain such freshwater habitat and the remaining populations of the freshwater crab by preventing suitable habitat from further fragmentation and shrinking. The latter would lead populations to inbreed, causing genetic erosion and reduced genetic variation, promoting the loss of fitness, reduction in the species' resilience and an increased risk of extinction (Keller \& Waller, 2002; Jamieson, 2009; Bijlsma \& Loeschcke, 2012; Miller et al., 2014; Nehemia \& Kochzius 2017; Mable, 2018). A signature of such occurrence is the unexpected lack of haplotype diversity at Lunzjata, Gozo. Our results indicate that the population on the island of Gozo must have either been recently established through a founder effect from a Maltese population or else this population has experienced one or more bottlenecks (Weber, Stewart \& Lehman, 2004; Tay et al., 2018; Wang, Zheng, Zhao \& Yao, 2019). Given 
that there are old records of the species in Gozo (Gavino, 1873) and that its occurrence has persistently been faced with threats, ranging from environmental degradation issues to harvesting, then the latter scenario is more likely. The management of this population needs urgent and careful conservation measures due to its lack of genetic variation, making it particularly vulnerable to extinction.

At this stage, all Maltese $P$. fluviatile fragmented populations, have to be safeguarded through regular conservation monitoring and effective habitat management. Currently, $P$. fluviatile is a nationally protected species in the Maltese archipelago (Laws of Malta, 2020), however both the species and the freshwater systems need urgent conservation management. Populations at San Martin, Baћrija and Mtaћleb exhibited distinctly unique genetic characteristics and are the most genetically diverse populations of $P$. fluviatile in the Maltese Islands, thus contributing to the richest gene pools, essential for the local resilience and future survival of the species.

\section{Conclusions}

The results of this study reveal the extent of genetic distinction among fragmented freshwater crab populations within the small geographical scale of the Maltese Islands. These populations show a strong relationship between their genetic diversity and the water system the specimens were sampled from. The pronounced population structure and lack of genetic connectivity between the different valleys investigated, point towards the immediate need to halt habitat shrinkage, degradation and further fragmentation. Reduction of the threats, across this species scattered distribution aimed to stop the declines in respective population sizes, may be achieved through conservation measures that ensure the species' populations long-term survivability and resilience through preservation of their genetic diversity.

\section{Acknowledgments}

This work was possible through the support of the Maltese Ministry for the Environment; the Environment Resource Authority (ERA); and the University of Malta, BioCon_Innovate Research Fund Award.

\section{References}

Barbaresi, S., Cannicci, S., Vannini, M. \& Fratini, S. (2007). Environmental correlates of two macro-decapods distribution in Central Italy: Multi-dimensional ecological knowledge as a tool for conservation of endangered species. Biological Conservation, 136: 431-441. https://doi.org/10.1016/j.biocon.2006.12.013

Bijlsma, R. \& Loeschcke, V. (2012). Genetic erosion impedes adaptive responses to stressful environments. Evolutionary Applications, 5: 117-129. https://doi.org/10.1111/j.1752-4571.2011.00214.x
Brandis, D., Storch, V. \& Türkay, M. (2000). Taxonomy and zoogeography of the freshwater crabs of Europe, North Africa, and the Middle East. Senckenbergiana Biologica, 80: 5-56.

Cachia, S. (1997). Aspects of the Behavioural ecology of the freshwater crab, Potamon fluviatile lanfrancoi, in the Maltese Islands. B.Sc. Thesis. Department of Biology, University of Malta.

Camilleri, A. \& Cachia, S. (2000). The freshwater crab Potamon fluviatile lanfrancoi: a newly discovered locality at IIWied ta' Gordajna and a clarification of records from IImtahleb. The Central Mediterranean Naturalist, 3(2): 79-84.

Capolongo, D. \& Cilia, J.L. (1990). Potamon fluviatile lanfrancoi, a new subspecies of a Mediterranean freshwater crab from the Maltese Islands (Crustacea, Decapoda, Potamidae). Annalen Naturhististorisches Museum, Wien, 91B: 215-224.

Chan, P.P. \& Lowe, T.M. (2019). tRNAscan-SE: Searching for tRNA Genes in Genomic Sequences. Methods in Molecular Biology, 1962: 1-14. https://doi.org/10.1007/978-1-4939-9173-0_1

Chen, P.C., Shih, C.H., Chu, T.J., Lee, Y.C. \& Tzeng, T.D. (2017). Phylogeography and genetic structure of the oriental river prawn Macrobrachium nipponense (Crustacea: Decapoda: Palaemonidae) in East Asia. PLoS ONE, 12(3): e0173490. https://doi.org/10.1371/journal.pone.0173490

Clement, M., Posada, D. \& Crandall, K.A. (2000). TCS: a computer program to estimate gene genealogies. Molecular Ecology, 9 (10): 1657-1659. https://doi.org/10.1046/j.1365-294x.2000.01020.x

Cumberlidge, N. (2008). Potamon fluviatile. The IUCN Red List of Threatened Species 2008: e.T134293A3933275. https://dx.doi.org/10.2305/IUCN.UK.2008.RLTS.T13429 3A3933275.en [Accessed: 15-11-2019].

Cumberlidge, N., Ng, P.K.L., Yeo, D.C.J., Magalhães, C., Campos, M.R., Alvarez, F., Naruse, T., Daniels, S.R., Esser, L.J., Attipoe, F.Y.K., Clotilde-Ba, F.L., Darwall, W., Mclvor, A., Baillie, J.E.M., Collen, B. \& Ramj, M. (2009). Freshwater crabs and the biodiversity crisis: Importance, threats, status, and conservation challenges. Biological Conservation, 142: 1665-1673. https://doi.org/10.1016/j.biocon.2009.02.038

Daniels, S.R., Gouws, G. \& Crandall, K.A. (2006). Phylogeographic patterning in a freshwater crab species (Decapoda: Potamonautidae: Potamonautes) reveals the signature of historic patterns of drainage and climate oscillations. Journal of Biogeography, 33: 1538-1549. https://doi.org/10.1111/j.1365-2699.2006.01537.x

Darriba, D., Taboada, G.L., Doallo, R. \& Posada, D. (2012). jModelTest 2: more models, new heuristics and parallel computing. Nature Methods, 9(8): 772. https://doi.org/10.1038/nmeth.2109

Debrincat, J. \& Schembri, P.J. (2007). Burrow density of the endangered Maltese Freshwater Crab Potamon fluviatile lanfrancoi at Lunzjata and Xlendi valleys, Gozo. Xjenza, 11: 1-9.

Duncan, S.I., Robertson, E.P., Fletcher, R.J. \& Austin, J.D. (2019). Urbanization and Population Genetic Structure of the Panama City crayfish (Procambarus econfinae). Journal of Heredity, esz072. https://doi.org/10.1093/jhered/esz072

Excoffier, L. \& Lischer, H.E.L. (2010). Arlequin suite ver 3.5: a new series of programs to perform population genetics analyses under Linux and Windows. Molecular Ecology 
Resources, $\quad 10 \quad$ (3): $\quad 564-567$. https://doi.org/10.1111/j.1755-0998.2010.02847.x

Fratini, S., Zaccara, S., Barbaresi, S., Grandjean, F., SoutyGrosset, C., Crosa, G. \& Gherardi, F. (2005). Phylogeography of the threatened crayfish (genus Austropotamobius) in Italy: implications for its taxonomy and conservation. Heredity, 94: 108-118. https://doi.org/10.1038/sj.hdy.6800581

Freyhof, J. \& Brooks, E. (2011). European Red List of Freshwater Fishes. Luxembourg: Publications Office of the European Union. https://doi.org/10.2779/85903

$\mathrm{Fu}$, Y.X. (1994). Estimating effective population size or mutation rate using the frequencies of mutations of various classes in a sample of DNA sequences. Genetics, 138: 1375-1386.

Fu, Y.X. (1997). Statistical tests of neutrality of mutations against population growth, hitchhiking and background selection. Genetics, 147: 915-925.

Furlani, S., Antonioli, F., Biolchi, S., Gambin, T., Gauci, R., Presti, V.L., Anzidei, M., Devoto, S., Palombo, M. \& Sulli, A. (2013). Holocene sea level change in Malta. Quaternary International, 288: 146-157. https://doi.org/10.1016/j.quaint.2012.02.038

Gavino G. (1873). Fauna Maltese: Indice dei Crostacei - II Barth. Gazzetta di Medicina e Scienze Naturali. 2(15-16): 314.

Gherardi, F., Messana, G., Ugolini, A. \& Vannini, M. (1988). Studies on the locomotor activity of the freshwater crab, Potamon fluviatile. Hydrobiologia, 169: 241-250. https://doi.org/10.1007/BF00007315

Gherardi, F., Tarducci, F. \& Micheli, F. (1989). Energy maximization and foraging strategies in Potamon fluviatile (Decapoda, Brachyura). Freshwater Biology, 22: 233-245. 2427.1989.tb01097.x

Google Earth (2019). Google Earth Pro v7.1. URL. http://www.google.com/earth/index.html [Accessed: 10-10-2019].

Gouin, N., Grandjean, F., Bouchon, D., Reynolds, J. \& SoutyGrosset, C. (2001). Genetic structure of the endangered freshwater crayfish Austropotamobius pallipes, assessed using RAPD markers. Heredity, 87: 80-87. https://doi.org/10.1046/j.1365-2540.2001.00909.x

Gouin, N., Souty-Grosset, C., Borquez, J., Bertin, A. \& Grandjean, F. (2010). Disentangling the impact of demographic factors on population differentiation of an endangered freshwater crayfish (Austropotamobius pallipes) using population density and microsatellite data. Freshwater Biology, 56: 2105-2118. https://doi.org/10.1111/j.1365-2427.2011.02629.x

Gozlan, R.E., Karimov, B.K., Zadereev, E., Kuznetsova D. \& Brucet S. (2019). Status, trends, and future dynamics of freshwater ecosystems in Europe and Central Asia. Inland Waters, 9(1): 78-94. https://doi.org/10.1080/20442041.2018.1510271

Grzybowski, M. \& Glińska-Lewczuk, K. (2019). Principal threats to the conservation of freshwater habitats in the continental biogeographical region of Central Europe. Biodiversity and Conservation, 28:4065-4097. https://doi.org/10.1007/s10531-019-01865-x

Harlıoğlu, M.M., Farhadi, A. \& Harlıoğlu, A.G. (2018). A review of the freshwater crabs of Turkey (Brachyura, Potamidae). Fisheries \& Aquatic Life, 26: 151-158. https://doi.org/10.2478/aopf-2018-0016

Harpending, H. \& Rogers, A. (2000). Genetic perspectives on human origins and differentiation. Annual Review of
Genomics and Human Genetics, 1: 361-385. https://doi.org/10.1146/annurev.genom.1.1.361

Harpending, H., Sherry, S.T., Rogers, A.R. \& Stoneking, M. (1993). The genetic structure of ancient human populations. Current Anthropology, 34 (4): 483-496. https://doi.org/10.1086/204195

Jaccarini, V. \& Harris, R.R. (1975). An Immunological comparison of Haemocyanins from Geographically isolated populations of some Brachyura (Decapoda). Comparative Biochemistry and Physiology Part A: Physiology, 50: 729-731. https://doi.org/10.1016/03009629(75)90136-X

Jamieson, I.G. (2009). Loss of genetic diversity and inbreeding in New Zealand's threatened bird species. Science for Conservation 293. $59 \mathrm{p}$.

Jesse, R., Grudinski, M., Klaus, S., Streit, B. \& Pfenninger, M. (2011). Evolution of freshwater crab diversity in the Aegean region (Crustacea: Brachyura: Potamidae). Molecular Phylogenetics and Evolution, 59: 23-33. https://doi.org/10.1016/j.ympev.2010.12.011

Jesse, R., Pfenninger, M., Fratini, S., Scalici, M., Streit, B. \& Schubart, C.D. (2009). Disjunct distribution of the Mediterranean freshwater crab Potamon fluviatile natural expansion or human introduction? Biological Invasions, 11: 2209. https://doi.org/10.1007/s10530008-9377-0

Jesse, R., Schubart, C.D. \& Klaus, S. (2010). Identification of a cryptic lineage within Potamon fluviatile (Herbst) (Crustacea: Brachyura: Potamidae). Invertebrate Systematics, 24: 348-356. https://doi.org/10.1071/IS10014

Kearse, M., Moir, R., Wilson, A., Stones-Havas, S., Cheung, M., Sturrock, S., Buxton, S., Cooper, A., Markowitz, S., Duran, C., Thierer, T., Ashton, B., Mentjies, P. \& Drummond, A. (2012). Geneious basic: an integrated and extendable desktop software platform for the organization and analysis of sequence data. Bioinformatics, 28 (12): 16471649. https://doi.org/10.1093/bioinformatics/bts199

Keikhosravi, A., Fratini, A., Christoph, D. \& Schubart. (2015). Population genetic structure and demographic history of the freshwater crab Potamon elbursi (Brachyura: Potamidae) from the Alborz Mountains in northern Iran. Journal of Limnology, 74: 512- 518. http://dx.doi.org/10.4081/jlimnol.2015.775

Keller, L.F. \& Waller, D.M. (2002). Inbreeding effects in wild populations. Trends in Ecology and Evolution, 17: 230241. https://doi.org/10.1016/S0169-5347(02)02489-8

Kimura, M. (1980). A simple method for estimating evolutionary rates of base substitutions through comparative studies of nucleotide sequences. Journal of Molecular Evolution, 16: 111-120. https://doi.org/10.1007/BF01731581

Kumar, S., Stecher, G. \& Tamura, K. (2016). MEGA7: molecular evolutionary genetics analysis version 7.0 for bigger datasets. Molecular Biology and Evolution, 33(7): 18701874. https://doi.org/10.1093/molbev/msw054

Laggis, A., Baxevanis, A.D., Charalampidou, A., Maniatsi S., Triantafyllidis, A. \& Abatzopoulos, T.J. (2017). Microevolution of the noble crayfish (Astacus astacus) in the Southern Balkan Peninsula. BMC Evolutionary Biology, 17: 122. https://doi.org/10.1186/s12862-0170971-6

Laslet D, Canbäck B. 2008. ARWEN: a program to detect tRNA genes in metazoan mitochondrial nucleotide sequences. 
Bioinformatics.

24, https://doi.org/10.1093/bioinformatics/btm573

Laws of Malta (2020). http://www.justiceservices.gov.mt/LOM.aspx?pageid=2 7\&mode=chrono [Accessed: 15-02-2020].

Mable, B.K. (2019). Conservation of adaptive potential and functional diversity: integrating old and new approaches. Conservation Genetics, 20: 89-100. https://doi.org/10.1007/s10592-018-1129-9

Micheli, M., Gherardi, F. \& Vannini, M. (1990). Growth and reproduction in the freshwater crab, Potamon fluviatile (Decapoda, Brachyura). Freshwater Biology, 23(3): 491503. https://doi.org/10.1111/j.1365-2427.1990.tb00290.x

Miller, A.D., Sweeney, O.F., Whiterod, N.S., Van Rooyen, A.R., Hammer, M. \& Weeks, A.R. (2014). Critically low levels of genetic diversity in fragmented populations of the endangered Glenelg spiny freshwater crayfish Euastacus bispinosus. Endangered Species Research, 25(1): 43-55. https://doi.org/10.3354/esr00609

Nehemia, A. \& Kochzius, M. (2017). Reduced genetic diversity and alteration of gene flow in a fiddler crab due to mangrove degradation. PLoSONE, 12(8): e0182987. https://dx.doi.org/10.1371\%2Fjournal.pone.0182987

NCBI (2020). National Center for Biotechnology Information, Blastn. URL. https://blast.ncbi.nlm.nih.gov/Blast.cgi [Accessed: 15-02-2020].

Pace F. (1974). A study of the development of Potamon edulis. M.Sc. thesis. Department of Biology, Royal University of Malta.

Pace, F., Harris, R.R. \& Jaccarini, V. (1976). The embryonic development of the Mediterranean freshwater crab, Potamon edulis ( $=$ P. fluviatile) (Crustacea, Decapoda, Potamonidae). Journal of Zoology, London, 180: 93-106. https://doi.org/10.1111/j.1469-7998.1976.tb04666.x

Parvizi, E., Keikhosravi, A., Naderloo, R., Solhjouy-Fard, S., Sheibak, F. \& Schubart, C.D. (2019). Phylogeography of Potamon ibericum (Brachyura: Potamidae) identifies Quaternary glacial refugia within the Caucasus biodiversity hot spot. Ecology and Evolution, 9: 47494759. https://doi.org/10.1002/ece3.5078

Rogers, A.J. \& Harpending, H. (1992). Population growth makes waves in the distribution of pairwise genetic differences. Molecular Biology and Evolution, 9: 552569.

https://doi.org/10.1093/oxfordjournals.molbev.a04072 7

Rozas, J., Ferrer-Mata, A., Sánchez-DelBarrio, J.C., Guirao-Rico, S., Librado, P., Ramos-Onsins, S.E. \& Sánchez-Gracia, A. (2017). DnaSP 6: DNA Sequence Polymorphism Analysis of Large Datasets. Molecular Biology and Evolution, 34: 3299-3302. https://doi.org/10.1093/molbev/msx248
Schneider, S. \& Excoffier, L. (1999). Estimation of past demographic parameters from the distribution of pairwise differences when the mutation rates vary among sites: application to human mitochondrial DNA. Genetics, 152: 1079-1089.

Sciberras, A., Sciberras, J. and Vella, S. (2009). On the occurrence of a new population of Potamon fluviatile at Wied Ghajn Żejtuna, Mellieћa, Malta. The Central Mediterranean Naturalist, 5(1): 24-27.

Slatkin, M. \& Hudson, R.R. (1991). Pairwise comparisons of mitochondrial DNA sequences in stable and exponentially growing populations. Genetics, 129: 555562.

Tajima, F. (1989). Statistical method for testing the neutral mutation hypothesis by DNA polymorphism. Genetics, 123: 585-595.

Tay Y.C., Ng, D.J.J, Loo, J.B., Huang, D., Cai, Y., Yeo, D.C.J. \& Meier, R. (2018). Roads to isolation: Similar genomic history patterns in two species of freshwater crabs with contrasting environmental tolerances and range sizes. Ecology and Evolution, 8: 4657-4668. https://doi.org/10.1002/ece3.4017

UGA Stratigraphy Lab, (2013). Analytic Rarefaction. https://strata.uga.edu/software/anRareReadme.html [Accessed: 15-02-2020].

Vecchioni, L., Deidun, A., Sciberras, J., Sciberras, A., Marrone, F. \& Arculeo, M. (2017). The late Pleistocene origin of the Italian and Maltese populations of Potamon fluviatile (Malacostraca: Decapoda): insights from an expanded sampling of molecular data. The European Zoological Journal, 84: 575-582. https://doi.org/10.1080/24750263.2017.1405084

Vella, N., Vella, A. \& Mifsud, C.M. (2017). First Scientific Records of the Invasive Red Swamp Crayfish, Procambarus clarkii (Girard, 1852) (Crustacea: Cambaridae) in Malta, a Threat to Fragile Freshwater Habitats. Natural and Engineering Sciences, 2: 58-66. https://doi.org/10.28978/nesciences.328931

Wang, W., Zheng, Y., Zhao, J. \& Yao, M. (2019). Low genetic diversity in a critically endangered primate: shallow evolutionary history or recent population bottleneck? BMC Evolutionary Biology, 19:134. https://doi.org/10.1186/s12862-019-1451-y

Weber, D.S., Stewart, B.S. \& Lehman, N. (2004). Genetic consequences of a severe population bottleneck in the Guadalupe Fur Seal (Arctocephalus townsendi). Journal of Heredity, 95(2): 144-153. https://doi.org/10.1093/jhered/esh018

Yamauchi, M.M., Miya, M.U. \& Nishida, M. (2003). Complete mitochondrial DNA sequence of the swimming crab, Portunus trituberculatus (Crustacea: Decapoda: Brachyura). Gene, 311: 129-135. https://doi.org/10.1016/S0378-1119(03)00582-1 